\title{
Secondary Treated Wastewater in Construction
}

\author{
Vidhya Lakshmi .A ${ }^{1}$, Arul Gideon. $\mathbf{R}^{2}$ \\ ${ }^{1,2}$ PG Student, Department of Civil Engineering, Sree Sastha Institute of Engineering and Technology, Chembarambakkam, Chennai, \\ TamilNadu-600123, India
}

\begin{abstract}
Human life, as with all animal and plant life on the planet, is dependent upon water. Not only do we need water to grow our food, generate our power and run our industries, but we need it as a basic part of construction purpose. Now at present stage water is in great demand in the field of construction. So as to fulfill the demand in this project the water used in concrete is replaced by secondary treated wastewater from Sewage water treatment plant. Sewage treatment is the process of removing contaminants from waste water and household sewage, both runoffs (effluents), domestic, commercial and institutional. It includes physical, chemical, and biological processes to remove the contaminants. The aim of the present research work is to investigate the possibility of using the secondary treated wastewater for the purpose of construction works on continuous basis. By evaluating and comparing the compressive and tensile strength of the conventional concrete cubes and secondary treated wastewater concrete cubes it is found that the strength obtained is greater in secondary treated wastewater concrete cubes. Hence, on the continuous basis secondary treated wastewater can be used for the construction purpose.
\end{abstract}

Keywords: Sewage treatment, contaminants, compressive and tensile strength.

\section{Introduction}

Concrete is the most commonly used building material. It has the advantage of being formed into any desired shape most conveniently. It is an artificial stone obtained by mixing aggregates, cement and water and allowing the product to cure for hardening. It's essential ingredients are cement and water which react with each other chemically, to form another material having the useful strength. The strength of concrete depends upon the quality of its ingredients, their relative quantities and the manner in which they are mixed, compacted and cured. It is possible to produce concrete of different specifications for various purposes by suitably adjusting the proportions of cement, aggregate and water.

\subsection{Requirements of Good Concrete}

The aggregate should be hard and durable. Aggregate should have proper gradation. It should contain adequate of cement so that it possess strength and water tightness. The water should be free from hardness and organic materials. It should possess good workability. Thorough mixing should be done so as to produce a homogenous mass. The temperature of concrete should be kept above freezing point until it gains the desired strength. This is necessary to ensure a uniform rate of hardening.

\subsection{Advantages of Concrete}

Concrete is economical in the long run as compared to other engineering materials. Concrete possess a high compressive strength, and the corrosive and weathering effects are minimal. When properly prepared, its strength is equal to the hard natural stone. The green concrete can be easily handled and moulded into any shape or size according to specifications. The formwork can be reused number of times of similar jobs resulting in economy. It is strong in compression and has unlimited structural applications in combination with steel reinforcement. Concrete can ever be sprayed on and filled into fine cracks for repairs by the grouting process.

\subsection{Disadvantages of Concrete}

Concrete has low tensile strength and hence easily cracking. Fresh concrete shrinks on drying and hardened concrete expands on wetting. Concrete expands and contracts with the changes in temperature. Concrete under sustained loading undergoes creep resulting in the reduction of prestress in entirely impervious to moisture and contains soluble salts, which may cause efflorescence. Concrete is liable to disintegrated by alkali and sulphate attack. The lack of ductility inherent in concrete as a material is disadvantageous with respect to earth quake resistant design.

\section{Treatment of Wastewater}

\subsection{Origin of Sewage}

Sewage is generated by residential, institutional, commercial and industrial establishments. It includes household waste liquid from toilets, baths, showers, kitchens, sinks and so forth that is disposed of via sewers. In many areas, sewage also includes liquid waste from industry and commerce. The separation and draining of household waste into greywater and blackwater is becoming more common in the developed world, with greywater being permitted to be used for watering plants or recycled for flushing toilets. Sewage may include storm water runoff. As rainfall travels over roofs and the ground, it may pick up various contaminants including soil particles and other sediment, heavy metals, organic compounds, animal waste, oil and grease. 


\section{International Journal of Science and Research (IJSR) \\ ISSN (Online): 2319-7064}

Index Copernicus Value (2013): 6.14 | Impact Factor (2015): 6.391

\subsection{Collection System}

The purpose of a sewage collection system is to remove wastewater from points of origin to a treatment facility or place of disposal. The collection system consists of the sewers (pipes and conduits) and plumbing necessary to convey sewage from the point of origin to the treatment system or place of disposal. It is necessary that the collection system be designed so that the sewage will reach the treatment system as soon as possible after entering the sewer. If the length of time in the sewers is too long, the sewage will be anaerobic when it reaches the treatment facilities. Sanitary sewage collection systems should be designed to remove domestic sewage only. Surface drainage is excluded to avoid constructing large sewers and treating large volumes of sewage diluted by rainwater during storms. Sewers which exclude surface drainage are called sanitary sewers, and those which collect surface drainage in combination with sanitary sewage are called combined sewers.

Except for force mains, sewers are laid to permit gravity flow of their contents. Usually the slope is such that a flow rate of 0.03 metre $(\mathrm{m})$ per second or more is maintained when the line is flowing half full to full. This is a self-cleansing velocity and prevents solids from settling in the sewer pipes. To the maximum extent practical, sewers are laid in straight lines. Corners and sharp bends slow the flow rate, permit clogging, and make line cleaning difficult. Pumping is necessary where the slope of the sewer does not produce the required minimum velocity of $0.03 \mathrm{~m}$ or where sewage must be lifted to a higher elevation. Sewage can be pumped from pumping stations through pressure lines regardless of their slope, or it can be raised to a higher elevation at pumping stations, so that gravity flow will again produce the required velocity.

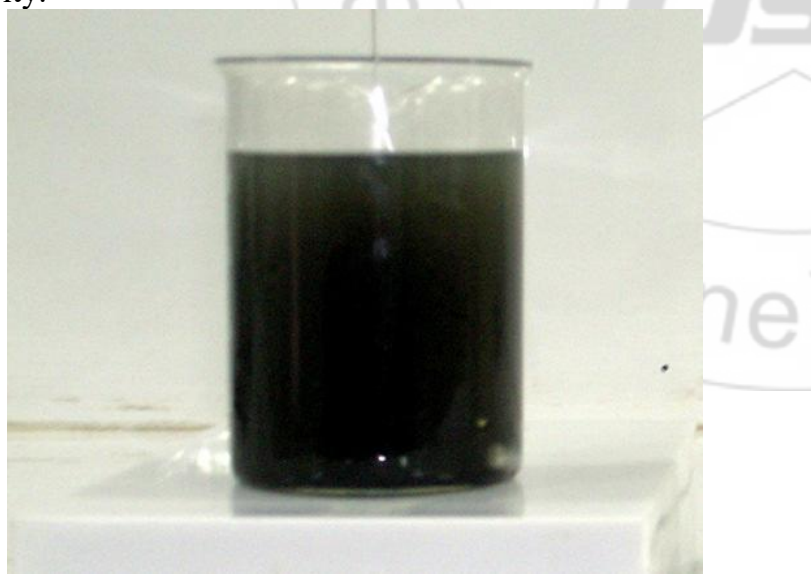

Figure 1: Raw Sewage

\subsection{Treatment Process}

Sewage can be treated close to where the sewage is created, a decentralized system, or be collected and transported by a network of pipes and pump stations to a municipal treatment plant, a centralized system. Sewage collection and treatment is typically subject to local, state and federal regulations and standards. Industrial sources of sewage often require specialized treatment processes.

Sewage treatment generally involves three stages,
1. Primary treatment.

2. Secondary treatment.

3. Tertiary treatment

\section{SEWAGE TREATMENT PROCESS}

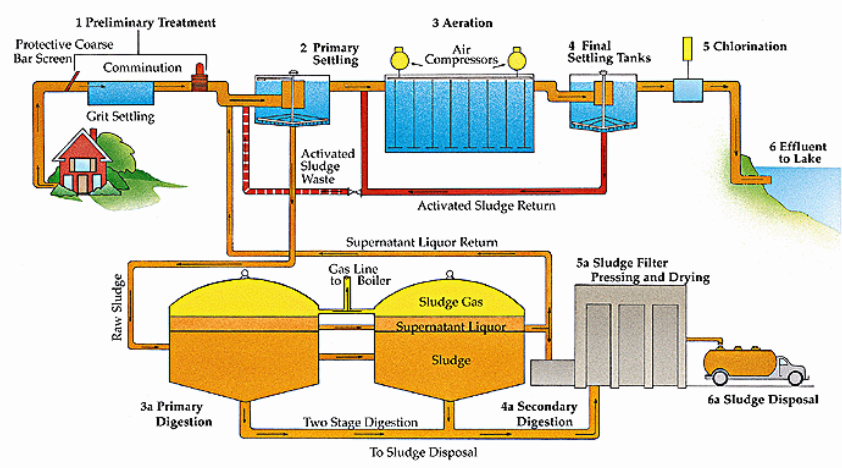

Figure 2: Sewage treatment process

\subsubsection{Primary Treatment}

Primary treatment consists of temporarily holding the sewage in a quiescent basin where heavy solids can settle to the bottom while oil, grease and lighter solids float to the surface. The settled and floating materials are removed and the remaining liquid may be discharged or subjected to secondary treatment. Pretreatment removes materials that can be easily collected from the raw sewage before they damage or clog the pumps and sewage lines of primary treatment clarifiers.

\subsubsection{Screening}

The influent sewage water passes through a bar screen to remove all large objects like cans, rags, sticks, plastic packets etc. carried in the sewage stream. This is most commonly done with an automated mechanically raked bar screen in modern plants serving large populations, while in smaller or less modern plants; a manually cleaned screen may be used. The raking action of a mechanical bar screen is typically paced according to the accumulation on the bar screens and/or flow rate. The solids are collected and later disposed in a landfill, or incinerated. Bar screens or mesh screens of varying sizes may be used to optimize solids removal. If gross solids are not removed, they become entrained in pipes and moving parts of the treatment plant, and can cause substantial damage and inefficiency in the process.

\subsubsection{Grit Chamber}

Pretreatment may include a sand or grit channel or chamber, where the velocity of the incoming sewage is adjusted to allow the settlement of sand, grit, stones, and broken glass. These particles are removed because they may damage pumps and other equipment. For small sanitary sewer systems, the grit chambers may not be necessary, but grit removal is desirable at larger plants. Grit chambers come in 3 types: horizontal grit chambers, aerated grit chambers and vortex grit chambers.

\subsubsection{Oil and Grease Removal}

In some larger plants, oil and grease are removed by passing the sewage through a small tank where skimmers collect the oil floating on the surface. Air blowers in the base of the tank 


\section{International Journal of Science and Research (IJSR) \\ ISSN (Online): 2319-7064}

Index Copernicus Value (2013): 6.14 | Impact Factor (2015): 6.391

may also be used to help recover the oil as froth. Many plants, however, use primary clarifiers with mechanical surface skimmers for oil and grease removal.

\subsubsection{Primary Clarifier}

After preliminary treatment the sewage flows into large round or rectangular tanks. In these the heavier organic material sinks to the tank floor and is swept by a scraper blade to a submerged outlet. From here it is pumped as slurry to a storage tank for subsequent treatment. Most of the solids in wastewater are removed in this process and concentrated into thick slurry which has a volume less than $1 \%$ of the sewage received at the works. This slurry is known as sewage sludge and it is dealt with separately. The liquid element (settled sewage) flows over a weir to the next stage of treatment.

\subsubsection{Secondary Treatment}

Secondary treatment removes dissolved and suspended biological matter. Secondary treatment is typically performed by indigenous, water-borne micro-organisms in a managed habitat. Secondary treatment may require a separation process to remove the micro-organisms from the treated water prior to discharge or tertiary treatment. Secondary treatment typically utilizes biological treatment processes, in which microorganisms convert nonsettleable solids to settleable solids. Sedimentation typically follows, allowing the settleable solids to settle out.

\subsubsection{Activated Sludge}

The most common option uses microorganisms in the treatment process to break down organic material with aeration and agitation, and then allows solids to settle out. Bacteria-containing "activated sludge" is continually recirculated back to the aeration basin to increase the rate of organic decomposition.

\subsubsection{Trickling Filters}

These are beds of coarse media (often stones or plastic) 3-10 $\mathrm{ft}$. deep. Wastewater is sprayed into the air (aeration), and then allowed to trickle through the media. Microorganisms attached to and growing on the media, break down organic material in the wastewater. Trickling filters drain at the bottom; the wastewater is collected and then undergoes sedimentation.

\subsubsection{Lagoons}

These are slow, cheap, and relatively inefficient, but can be used for various types of wastewater. They rely on the interaction of sunlight, algae, microorganisms, and oxygen (sometimes aerated). After primary and secondary treatment, municipal wastewater is usually disinfected using chlorine or other disinfecting compounds, or occasionally ozone or ultraviolet light.

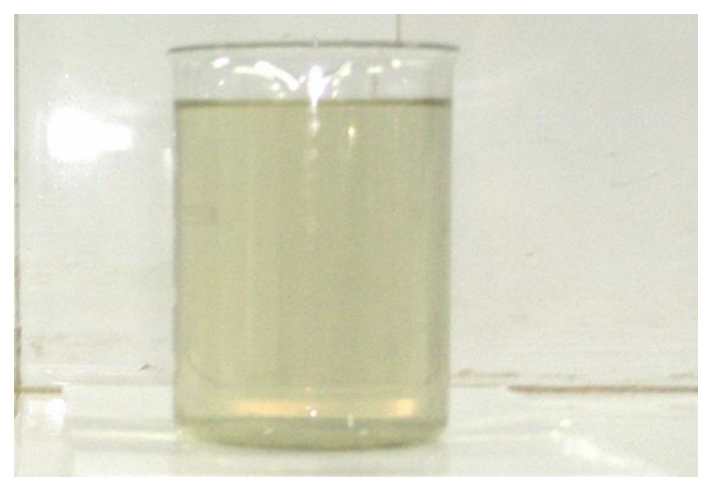

Figure 3: Secondary treated wastewater

\subsection{Wastewater Treatment Facts}

1)Each person produces approximately 150 liters of wastewater per day containing $60 \mathrm{~g}$ of organic matter. A large proportion of this water is actually used to flush away waste and carry it to the treatment works.

2) Each person produces on average $55 \mathrm{~g}$ of bio solids per day as dried solids, or $20 \mathrm{~kg}$ per annum

3) Sewage is $99.9 \%$ water and the wastewater treatment process is designed to treat the $0.1 \%$ solids.

4) The better the treatment, the more sludge is produced. As our environment has improved more and more sludge's are being produced.

5)The water industry invests millions of pounds each year in research to improve its understanding of wastewater treatment, sludge treatment and biosolids recycling to ensure protection of public health and the environment.

\section{Materials and Methods}

\subsection{Materials}

The materials used in this research work are ordinary Portland cement of 53 grade, river sand, coarse aggregate of $20 \mathrm{~mm}$ nominal size and secondary treated waste water.

\subsection{Preparation of Specimens}

Concrete mix proportions of ratio $1: 1.5: 3$ is used for the preparation of specimens. Conventional and Secondary treated wastewater specimens were casted in parallel. The specimens were cured under tap water at room temperature and tested at the age of 7,14 and 28days.

\section{Tests on Concrete}

\subsection{Compressive Strength Test}

The casted specimens of size $150 \mathrm{~mm} * 150 \mathrm{~mm} * 150 \mathrm{~mm}$ cubes and size $150 \mathrm{~mm} * 300 \mathrm{~mm}$ cylinders were tested to determine the compressive strength at the age of 7,14 and 28days. The results of the tested specimens for compressive strength are presented in Table 5.

\subsection{Split Tensile Test}

The sizes of $150 \mathrm{~mm} * 300 \mathrm{~mm}$ cylinders were tested to determine the split tensile strength at the age of 7,14 and 


\section{International Journal of Science and Research (IJSR) \\ ISSN (Online): 2319-7064}

Index Copernicus Value (2013): 6.14 $\mid$ Impact Factor (2015): 6.391

28days. The results of specimens tested for split tensile strength are presented in Table 8 .

Table 1: Compressive strength of conventional concrete cubes

\begin{tabular}{|c|c|c|c|c|}
\hline \multirow{2}{*}{ Trial } & \multirow{2}{*}{ Specimen } & \multicolumn{3}{|c|}{ Compressive Strength $\left(\mathrm{N} / \mathrm{Mm}^{2}\right)$} \\
\cline { 3 - 5 } & & 7 days & 14 days & 28 days \\
\hline 1 & Conventional & 18.21 & 26.83 & 34.66 \\
\cline { 4 - 5 } & Concrete & 19.69 & 27.12 & 32.01 \\
\cline { 3 - 5 } 2 & Cubes & 18.94 & 26.45 & 30.22 \\
\hline 3 & & &
\end{tabular}

Table 2: Compressive strength of secondary treated wastewater concrete cubes

\begin{tabular}{|c|c|c|c|c|}
\hline \multirow{2}{*}{ Trial } & \multirow{2}{*}{ Specimen } & \multicolumn{3}{|c|}{ Compressive Strength $\left(\mathrm{N} / \mathrm{Mm}^{2}\right)$} \\
\cline { 3 - 5 } & & 7 days & 14 days & 28 days \\
\hline 1 & Secondary Treated & 28.86 & 39.96 & 44.40 \\
\cline { 4 - 5 } & Wastewater & 26.72 & 36.99 & 41.10 \\
\cline { 3 - 5 } & Concrete Cubes & 26.14 & 36.21 & 40.22 \\
\hline
\end{tabular}

Table 3: Compressive strength of conventional concrete cylinders

\begin{tabular}{|c|c|c|c|c|}
\hline \multirow{2}{*}{ Trial } & \multirow{2}{*}{ Specimen } & \multicolumn{3}{|c|}{ Compressive Strength $\left(\mathrm{N} / \mathrm{Mm}^{2}\right)$} \\
\cline { 3 - 5 } & & 7 days & 14 days & 28 days \\
\hline 1 & \multirow{2}{*}{\begin{tabular}{c} 
Conventional \\
Concrete \\
\cline { 3 - 5 }
\end{tabular}} & 18.38 & 25.46 & 28.29 \\
\cline { 3 - 5 } & Cylinders & 16.12 & 22.41 & 24.89 \\
\cline { 3 - 5 } & & 13.24 & 18.33 & 20.37 \\
\hline
\end{tabular}

Table 4: Compressive strength of Secondary treated wastewater concrete cylinders

\begin{tabular}{|c|c|c|c|c|}
\hline \multirow{2}{*}{ Trial } & \multirow{2}{*}{ Specimen } & \multicolumn{3}{|c|}{ Compressive Strength $\left(\mathrm{N} / \mathrm{Mm}^{2}\right)$} \\
\cline { 3 - 5 } & & 7 days & 14 days & 28 days \\
\hline 1 & Secondary Treated & 20.59 & 28.51 & 31.68 \\
\cline { 4 - 5 } 2 & Wastewater Concrete & 19.13 & 26.49 & 29.43 \\
\cline { 3 - 5 } & Cylinders & 16.92 & 23.43 & 26.03 \\
\hline
\end{tabular}

Table 5: Comparison of compressive strength of conventional concrete and secondary treated wastewater concrete

\begin{tabular}{|c|c|c|}
\hline $\begin{array}{c}\text { S. } \\
\text { No }\end{array}$ & Specimen & $\begin{array}{c}\text { Average of Compressive } \\
\text { Strength }\left(\mathrm{N} / \mathrm{Mm}^{2}\right)\end{array}$ \\
\hline 1 & Conventional concrete cubes & 32.29 \\
\hline 2 & $\begin{array}{c}\text { Secondary treated wastewater } \\
\text { concrete cubes }\end{array}$ & 41.91 \\
\hline 3 & Conventional concrete cylinders & 24.52 \\
\hline 4 & $\begin{array}{c}\text { Secondary treated wastewater } \\
\text { concrete cylinders }\end{array}$ & 29.04 \\
\hline
\end{tabular}

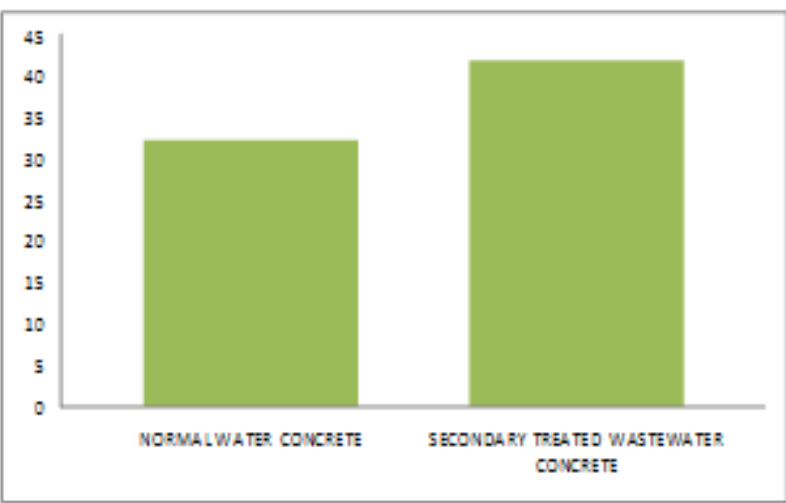

Figure 4: Compressive strength of cubes

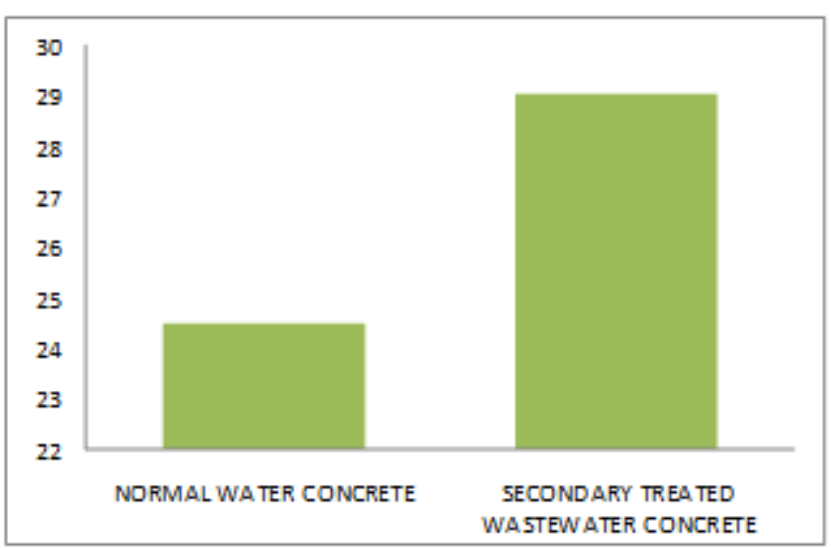

Figure 5: Compressive strength of cylinders

Table 6: Tensile strength of conventional concrete cylinders

\begin{tabular}{|c|c|c|c|}
\hline Trial & Specimen & $\begin{array}{c}\mathrm{P} \\
(\mathrm{N})\end{array}$ & $\begin{array}{l}\text { Tensile Strength } 2 \mathrm{p} /(\text { Пld }) \\
\left(\mathrm{N} / \mathrm{Mm}^{2}\right)\end{array}$ \\
\hline 01 & \multirow{3}{*}{$\begin{array}{c}\text { Conventional } \\
\text { Concrete } \\
\text { cylinders }\end{array}$} & 38500 & 0.545 \\
\hline 02 & & 32700 & 0.462 \\
\hline 03 & & 28500 & 0.403 \\
\hline
\end{tabular}

Table -7: Tensile strength of conventional concrete cylinders

\begin{tabular}{|c|c|c|c|}
\hline Trial & Specimen & $\begin{array}{l}\mathrm{P} \\
(\mathrm{N})\end{array}$ & $\begin{array}{c}\text { Tensile Strength } 2 \mathrm{p} /(\text { (Ild }) \\
\left(\mathrm{N} / \mathrm{Mm}^{2}\right)\end{array}$ \\
\hline 01 & \multirow{3}{*}{$\begin{array}{c}\text { Secondary treated } \\
\text { wastewater concrete } \\
\text { cylinders }\end{array}$} & 43500 & 0.615 \\
\hline 02 & & 38000 & 0.537 \\
\hline 03 & & 34500 & 0.488 \\
\hline
\end{tabular}

Table 8: Comparison of tensile strength of conventional concrete and secondary treated wastewater concrete

\begin{tabular}{|c|c|c|}
\hline $\begin{array}{c}\text { S. } \\
\text { No }\end{array}$ & Specimen & $\begin{array}{c}\text { Average of Tensile } \\
\text { Strength }\left(\mathrm{N} / \mathrm{mm}^{2}\right)\end{array}$ \\
\hline 01 & Conventional Concrete & 0.470 \\
\hline 02 & $\begin{array}{c}\text { Secondary treated wastewater } \\
\text { Concrete }\end{array}$ & 0.546 \\
\hline
\end{tabular}

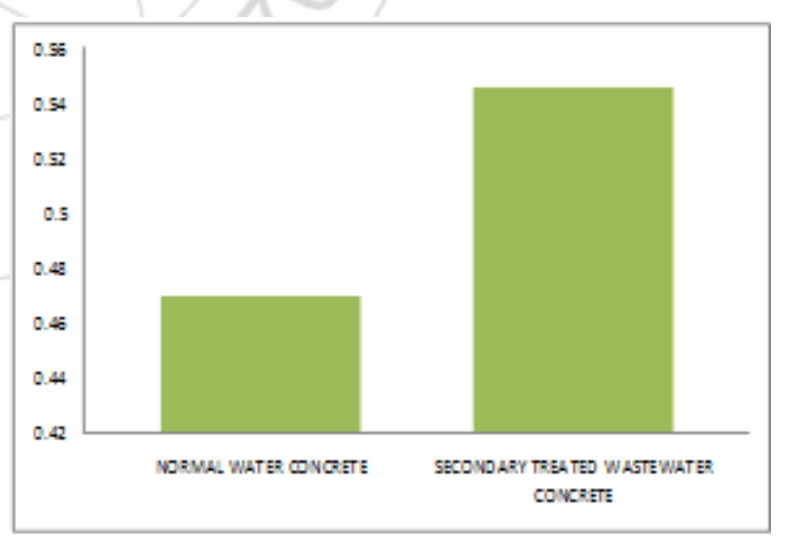

Figure 6: Tensile strength of cylinders

\section{Results and Discussion}

The various results obtained from the compressive strength test and split tensile strength tests were discussed and tabulated. The charts representing the test results were also provided. The table 5 indicates the results of the compressive strength of the cubes and cylinders whereas the table 8 indicates the results of the tensile strength of the cylinders. 


\section{International Journal of Science and Research (IJSR) \\ ISSN (Online): 2319-7064}

Index Copernicus Value (2013): 6.14 | Impact Factor (2015): 6.391

\subsection{Conclusions}

From the experimental result the following conclusions were made:

- Tests performed in this study suggest that secondary treated wastewater is an interesting candidate for use in concretes for applications in the mixture.

- There is a significant increase in the load carrying capacity, the compressive strength of the secondary treated wastewater concrete when compared with the conventional concrete.

- The compressive strength is $9.62 \%$ more in case of concrete cubes confined with secondary treated wastewater.

- Concrete prepared by using secondary treated wastewater gives aesthetically pleasant appearance.

- It is found that the compressive strength and tensile strength in secondary treated wastewater concrete increases when compared with the conventional concrete.

\section{References}

[1] Al-Ghousian, I. \& Terro, M.(2002), "Use of Treated Wastewater for Concrete Mixing in Kuwait, Kuwait Journal of Science and Engineering, Vol.30, Issue 1:213-28.

[2] Mohammad Shekarchi, Mahdi yazdian and Naser Mehrdadi,(2012) "Use of Biologically Treated domestic Waste Water in Concrete", Construction Material Institute, College of Engineering, University of Tehran, Tehran, Iran.Kuwait Journal of Science and Engineering 39(2B) PP.97-111,

[3] Cement concrete and aggregates Australia (2012) "Use of recycled water in concrete production" Western Australia August

[4] Al-Jabri KS, Taha R and Al-Saidy AH (2010). Effect of using non-fresh water on the mechanical properties of cement mortars and concrete. Proceedings The Third International fib Congress and PCI Annual Convention \& Exhibition, May 29 - June 2, Washington D. C., USA.

[5] Cebeci OZ, and Saatci AM (1989). Domestic sewage as mixing water in concrete, ACI Materials Journal. 86(5), pp. 503-506.

[6] Chini AR, Muszyasti LC, and Ellis PS (1999). Recycling process water in ready-mixed concrete operations. Final Report Submitted to the Florida Department of Transportation, University of Florida, Gainesville, FL.

[7] El-Nawawy OA, and Ahmad S (1991). Use of treated effluent in concrete mixing in an arid climate. Cement and Concrete Composites. 13(2), pp. 137-141.

[8] Taha R, Al-Rawas A, Al-Oraimi ., Hassan H, and AlAghbari M (2005). The use of brackish and oilcontaminated water in road construction, Environmental and Engineering Geoscience. XI(2), pp. 74-150.

[9] Taha R, Al-Harthy AS, and Al-Jabri KS (2010). Use of production and brackish water in concrete. Proceedings International Engineering Conference on Hot Arid Regions (IECHAR 2010. March 1-2, Al-Ahsa, Kingdom of Saudi Arabia, pp. 127-132.

[10] Vinut Kulkarni, Suresh G Patil. A Study on Compressive Strength of Concrete Using Treated Domestic Waste 